\title{
Organ donation in the accident and emergency department: a study of relatives' views
}

\author{
A Wellesley, E Glucksman, R Crouch
}

\begin{abstract}
Objective-To determine whether recently bereaved people would object to being asked about organ donation immediately after the death of their relative.

Methods-A telephone interview of 78 recently bereaved relatives of people who had died in an inner city accident and emergency (A\&E) department; 68 (87\%) agreed to participate in the study and were sent a questionnaire. Outcome measures were views on being asked about organ donation in the $A \& E$ department immediately after the death of a relative and knowledge of the possibility for organ donation in A\&E after a sudden death.

Results-37 questionnaires were returned: $27(72.9 \%)$ of those who responded would not have minded being asked, five would have minded, and five did not know or did not fill in the questionnaire; 29 were aware that organs could be donated following a death in A\&E.

Only six people had discussed organ donation before the bereavement. Only two of the people who died and seven of their relatives carried a donor card. Sixteen had heard about the NHS donor register.

Conclusions-Most those responding would not have minded being asked about organ donation following a sudden death. More education is needed in two main areas: (1) to raise public awareness about the shortage of donor organs; (2) to improve the medical and nursing confidence in discussing these difficult issues sensitively but more openly and frequently.

( Accid Emerg Med 1997;14:24-25)
\end{abstract}

Keywords: organ donation; relatives; potential donors in $\mathrm{A} \& \mathrm{E}$

There is a great shortage of organs for donation, this lack continues to limit transplant efforts $^{1-3}$ and the demand is growing at a much greater rate than the supply. ${ }^{1}$ Studies have shown that the usage of potential organs from the accident and emergency (A\&E) department is very low. ${ }^{3}$ Increasing the supply of these potential organs from the $A \& E$ department was one of the options that was put forward by the Royal Colleges working party. ${ }^{1}$

The purpose of this study was to explore the views of recently bereaved relatives about organ donation. Organs that can be donated from $\mathrm{A} \& \mathrm{E}$ include corneas and heart valves and in certain departments kidneys. ${ }^{4}$ The contraindications are few. For heart valves there must be no congenital valve defect, no systemic infection, no hepatitis B or C, and the donor must not be HIV positive. For corneas there are even fewer: no scarring of the cornea, no infection in the eye, and no invasive brain tumours which may infiltrate eye tissue (UK Transplant Co-ordinators Association). Both organs are very successfully transplanted, with at least $85 \%$ success for corneas and even higher for heart valves, due to the absence of rejection problems. Both are important in restoring health to the recipients and are viewed as worthwhile procedures.

\section{Methods}

A telephone interview to seek permission for inclusion in the study and a questionnaire survey of recently bereaved relatives was conducted. Over a three week period 129 contacts were attempted by telephone with relatives of people who had died in King's College Hospital accident and emergency department in the period between three and 12 months before the start of the study, using phone numbers given at the time of their bereavement. Seventy eight contacts were successful and permission was then sought to send a questionnaire, the outline of which was explained. The questionnaire was sent to the 68 who gave their permission, with a covering letter explaining the reason for the study and the importance of their response. The questionnaire asked two specific questions about organ donation in the $A \& E$ department, and then a section of seven questions about organ donation in general. Respondents were also asked their age and relationship to the person who had died.

A further letter was sent to everyone thanking them for their help and asking those who had not responded to do so. Following this, two further responses were received.

\section{Results}

Thirty seven questionnaires were returned, a response rate of $54.5 \%$. Three were not completed but were accompanied by letters explaining they were still too distressed to fill in the questionnaires.

Twenty seven $(73 \%)$ of those who responded stated that they would not have minded being asked about organ donation in casualty, five $(13.5 \%)$ would have minded, and two $(5.4 \%)$ were not sure. Of those who would not have wanted to be asked, three were elderly widows, one a younger widow, and one a mother who had lost a son. Another mother whose son had died said she would have welcomed being asked.

Twenty nine $(78 \%)$ of the respondents knew that organs could be donated from $A \& E$. 


\begin{tabular}{|c|c|c|c|}
\hline \multirow[b]{2}{*}{ Question } & \multicolumn{2}{|c|}{ Response $(n=34)$} & \multirow[b]{2}{*}{ Comment } \\
\hline & Yes & No & \\
\hline Had organ donation been discussed with your relative? & $6(18 \%)$ & $28(79 \%)$ & 2 general discussion \\
\hline Did your relative carry a donor card? & $2(6 \%)$ & $30(88 \%)$ & 2 don't know \\
\hline If your relative carried a donor card, do you feel you should have been asked to confirm their intention or wishes? & $26(76 \%)$ & $7(21 \%)$ & 1 no response \\
\hline Do you carry a donor card? & $7(21 \%)$ & $27(79 \%)$ & 2 too old \\
\hline Have you heard about the NHS donor register? & $16(47 \%)$ & $18(53 \%)$ & \\
\hline Do you think the age at which someone dies should affect whether organs are used for donation? & $17(50 \%)$ & $17(50 \%)$ & $\begin{array}{l}\text { Not if very young } \\
\text { or very elderly }\end{array}$ \\
\hline Do you think the cause of death should have a bearing on whether organs should be donated? & $23(68 \%)$ & $11(32 \%)$ & \\
\hline
\end{tabular}

The age of the relatives who responded ranged from 28-90 years, there were 24 responses from female relatives, of whom 12 were wives who had lost their husbands. Of the 10 responses from male relatives there were five who had lost a parent and two who had lost their wives.

The results of the questions about organ donation in general are shown in the table.

\section{Discussion}

The findings of this study indicate that the majority of respondents would not have minded being asked, despite the need to ask so soon after an unexpected bereavement. The response rate was $54.5 \%$, but given that the nature of the inquiry was about a particularly sensitive area and difficult to follow up, this seems reasonable. Even assuming the 10 people who did not consent to being sent a questionnaire would not have wanted to be asked about organ donation, $56 \%$ still would not have minded being asked.

The study also suggests that the subject of organ donation is not a popular topic of discussion within families. Only $18 \%$ had discussed the subject before the death of their relative. Of these, two had only discussed it in general terms. This is illustrated by comments such as "Only generally as he was 23 and unlikely to die", and "No, it always being thought that I would die first". Despite all the recent government publicity only two relatives and six people filling in the questionnaires carried donor cards $(12 \%)$. The most common reason given for not carrying a card was that the respondents thought they were too old. As there are no age limits for corneal donation this is a unfortunate misconception. Almost $80 \%$ of people thought that even if their relatives carried donor cards they should be consulted and should give their permission before organ donation took place. Only 16 people $(47 \%)$ had heard about the NHS donor register which was set up in 1994 to try to improve the number of organs available for donation.

The issue of approaching grieving relatives to ask about cadaveric organs was identified by Stein et $\mathrm{al}^{1}$ and the Royal Colleges' working party document on the supply of donor organs for transplantation. We have shown that the majority of relatives who responded would not have minded being asked about organ donation and may, in some circumstances, have welcomed it. The option of organ donation may help rather than hinder bereaved parents. ${ }^{5}$

Several investigators have shown that medical and nursing staff find it very difficult and stressful to ask about organ donation ${ }^{167}$ and that breaking bad news is not always handled well by them. ${ }^{89}$ There is a need for improved teaching and back up for those staff members who are involved in giving relatives bad news, since the way people are told of the death of a relative has a large impact on the way they react and the way they cope with the loss. ${ }^{5} 1011$

How might the subject of organ donation be broached in $A \& E$ ? One possible method would be leaflets in the room where relatives are given the bad news, as a way of introducing this delicate subject and providing more information. Comprehensive leaflets are produced by the UK Transplant Coordinators' Association covering specific organs and organ donation in general. General information about organ donation could also be available in the waiting area within the $A \& E$ department to increase everyone's awareness about the issues and problems. As heart valves and corneas do not have to be removed immediately, relatives who are not sure can take away these leaflets and discuss the issue later after the initial shock has passed.

Although this was only a small study using relatives from one inner city $A \& E$ department, the results were very positive and indicate a need for more work to be done in this field. The study suggests that relatives should be asked about organ donation after a sudden death. The interview needs to be carried out sensitively by senior A\&E staff-that is, senior nurses, registrars, or in some circumstances the consultant-who have been appropriately trained and who have access to staff support within the department.

1 Stein A, Hope T, Baum JD. Organ transplantation: approaching the donor's family. BMJ 1995;310:1149-50. Cheung AH, Luna GK. Cadaveric organ donor availability. J Trauma 1990;11:1366-71.

Riker RR, White BW. Organ and tissue donation from the emergency department. J Emerg Med 1991;9:405-10.

4 Varty K, Veitch PS, Morgan JDT, Keninde EO, Donnelly PK, Bell PRF. Response to organ shortage: kidney retrieval programme using non-heart beating donors. BMJ 1994; 308:575.

5 Finley I, Dallimore D. Your child is dead. BMJ 1991;302: 1524-5.

6 Swisher LA, Nieman LZ, Nilsen GJ, Spivey WH. Death notification in the emergency department: a survey of residents and attending physicians. Ann Emerg Med 1993;22: dents and

7 Ewins D, Bryant J. Relative comfort. Nursing Times 1992 ; 88:61-3.

8 McManus IC, Vincent CA, Thom S, Kidd J. Teaching communication skills to clinical students. BMJ 1993;306: munication

9 Schmidt TA, Norton RL, Tolle SW. Sudden death in the ED, educating residents to compassionately inform families. J Emerg Med 1992;10:643-7.

10 Yates DW, Ellison G, McGuiness S. Care of the suddenly bereaved. BMJ 1990;301:29-31.

11 Adamowski K, Dickinson G, Weitzman B, Roessler C, Carter Snell C. Sudden unexpected death in the emergency department: caring for the survivors. Can Med Assoc 1993;149:1445-51. 